\title{
What do Airbnb users care about? An analysis of online review comments
}

Dr Mingming Cheng*,

Department of Tourism, Otago Business School, University of Otago, New Zealand

Dr Xin Jin,

Department of Tourism, Sport and Hotel Management, Griffith University, Australia

\begin{abstract}
This study investigates the attributes that influence Airbnb users' experiences by analysing a "big data" set of online review comments through the process of text mining and sentiment analysis. Findings reveal that Airbnb users tend to evaluate their experience based on a frame of reference derived from past hotel stays. Three key attributes identified in the data include 'location', 'amenities' and 'host'. Surprisingly, 'price' is not identified as a key influencer. The analysis suggests a positivity bias in Airbnb users' comments while negative sentiments are mostly caused by 'noise'. This research offers an alternative approach and more coherent understanding of the Airbnb experience. Methodologically, it contributes by illustrating how big data can be used and visually interpreted in tourism and hospitality studies.
\end{abstract}

Keywords: Airbnb, user experience, unsupervised learning, big data, sentiment analysis 


\section{Introduction}

The sharing economy phenomenon is driven by people's desire for sustainability, enjoyment of the activity and economic gains (Hamari, Sjöklint, \& Ukkonen, 2015), which has sparked mounting interest from researchers and business. The sharing economy has enabled people to engage in selling services through reputable online platforms such as Uber or Airbnb. The focus of this article is on Airbnb, a peer-to-peer internet platform provider that has become one of the most successful models in the sharing economy. Airbnb has gained rapid popularity among its users across the world. Since its establishment in San Francisco in 2008, it has experienced rapid growth connecting a total number of more than 200 million guests across more than 65,000 cities (Airbnb, 2017). Its rapid growth has changed the way the business community have come to view it (Cheng, 2016). Arguably, Airbnb disrupted the whole established hotel system with an estimated value of $\$ 30$ billion, which is ahead of most hospitality groups (Skift, 2016). Some analysts estimate that in the next five years, Airbnb will rack up half a billion "room nights" per year with the potential to grow to a full billion annually by 2025 (Verhage, 2016).

Given its popularity and reach in the tourism and hospitality industry, researchers have begun undertaking systematic studies on the Airbnb phenomenon, shifting from a media portrayed paradigm to a research driven agenda. Existing research has examined Airbnb's potential disruption to the established accommodation sector (Guttentag, 2015), price strategies (Wang \& Nicolau, 2017), advertising appeals (Liu \& Mattila, 2017), potential discrimination (Edelman, Luca, \& Svirsky, 2016), impact on labour (Fang, Ye, \& Law, 2015), and Airbnb user behaviour and experiences (Tussyadiah, 2016). A key attribute of the Airbnb user experience is its ability to offer an authentic tourist-host encounter that cannot be replicated in conventional hotels (Tussyadiah, 2016). Yet, statistics reveal that many Airbnb users are likely to have limited interactions with their hosts, as many hosts simply rent out the entire apartment without their presence. For example, in Sydney, Australia, 61.9\% of the 23,615 listings are for entire home/apartment (see Figure 1, red). In addition, the attributes of the hosts such as 'friendliness' and 'attentiveness' might not always be identified as an important dimension of the Airbnb experience. Also the authentic tourist-host exchange is unlikely to represent an interaction between people of differing cultures and worldviews given that they generally occur between privileged like-minded people (Dredge \& Gyimóthy, 2015). Researchers are questioning the importance of the host-guest interaction by identifying other key attributes of Airbnb (Tussyadiah \& Zach, 2016) and examining the differences between it and staying in a hotel (Belarmino, Whalen, Koh, \& Bowen, 2017; Guttentag \& Smith, 2017). Yet, the existing research as yet to synthesise these two aspects in detail, although Belarmino et al. (2017) and Bridges and Vasquez (2016) have provided some initial comparative insights between Airbnb and hotels based on relatively small sample sizes. Also, existing studies focus mainly on identifying concepts at the macro level without sufficient attention been paid to the nuanced aspects of the Airbnb experience, such as what elements are involved when related to 
"host" or "location", which can be ambiguous for researchers and practitioners to develop a coherent knowledge to conceptualize peer-to-peer accommodation experience and formulate relevant strategies.

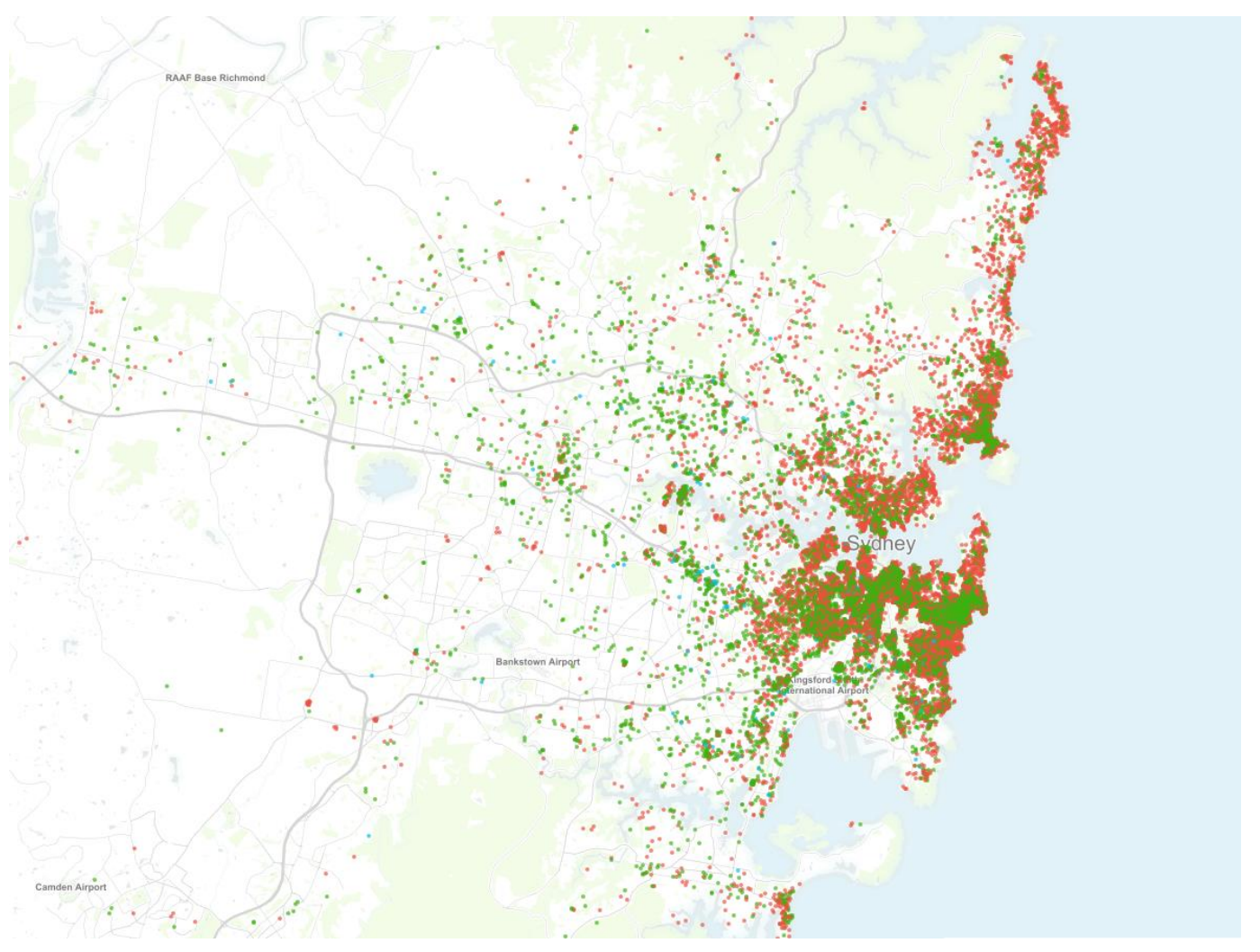

Figure 1: The geo-location of each listing in Sydney

* Red - entire home/apartment, green- private room

*23,615 listings at the end 2016 with $61.9 \%$ of entire home/apartment (red) and with 181,263 reviews.

This study investigates the attributes that influence Airbnb users' experiences by analysing a "big data" set of online review comments of users staying in Sydney. The study employs text mining and sentiment analysis to analyse the online reviews. It seeks to address the call by Tussyadiah and Zach (2016) to employ sentiment analysis to identify Airbnb users' positive and negative opinions in order to contribute to the debate on Airbnb user experiences. The study employed an inductive approach to text-mining (i.e., content analysis of Airbnb user review comments) to identify key attributes. Based on this logic, it builds from the data to identify a set of broad themes that characterise the attributes that influence Airbnb users' experiences. It therefore avoids where possible pre-figuring theories and hypotheses about the possible experience (Goddard \& Melville, 2001). However, we summarised hotel attributes reported in the literature and used these as a frame of reference to generate additional insights on similarities and differences between Airbnb and hotel attributes, in order to better understand Airbnb's potential disruption to the established hotel and accommodation industry. The study contributes to the sharing economy and hospitality literatures by providing a coherent and detailed 
understanding of the Airbnb user experience. Methodologically, it contributes by illustrating how big data can be used and visually interpreted in tourism and hospitality studies.

The paper is organized as follows. First, it reviews the existing literature on user experience of Airbnb, hotel attributes and big data. The research design follows with details on the four stages of data analysis. Findings and discussions are then presented with quotes from the visitors review comments. The paper concludes with a summary of the main findings, contribution to theory and practice, and avenues for future research.

\section{Literature review}

\section{User experience of Airbnb}

The rapid growth of Airbnb, with its distinct operation model, not only offers an alternative accommodation experience for its users, but it also challenges the theories and practices developed from the conventional hotel industry (Bridges \& Vásquez, 2016; Cheng, 2016; Tussyadiah \& Pesonen, 2015; Zervas, Proserpio, \& Byers, 2017). Airbnb refers to itself as a distinct internet platform by establishing "a trusted community marketplace for people to list, discover, and book unique accommodation around the world" and "connects people to unique travel experiences" (Airbnb, 2017). With Airbnb's promise to provide a unique human-to-human experience, researchers have embarked on investigations to identity the dimensions/attributes that form the basis of the Airbnb experience.

Existing empirical studies on the phenomenon have produced a variety of similar but sometimes contradictory evidence. The order of importance of each Airbnb experience dimension also varies in different studies. Earlier studies treated the social (guest-host) interactions as a core dimension of the Airbnb experience (Festila \& Müller, 2017; Lampinen \& Cheshire, 2016; Tussyadiah \& Pesonen, 2015; Yannopoulou, 2013). For example, Yannopoulou (2013) argues that Airbnb essentially entails "meaningful life enrichment, human contact, access and authenticity" (p. 89). Other researchers are less comfortable with such claims and suggest that, for some users, Airbnb is just a hotel-like experience at a relatively lower cost (Festila \& Müller, 2017). Guttentag (2016) found that Airbnb users highly value practical attributes, and somewhat less so of its experiential attributes. Even with the practical attributes, 'location' was found to not be statistically significant in influencing Airbnb users' satisfaction, whereas 'enjoyment', 'amenities' and 'cost saving' were ranked positively (in order of significance) (Tussyadiah, 2016). The reasons for these contradictory findings are still somewhat unclear; but researchers suggest that this might be attributable to the lack of standard of Airbnb accommodations (Tussyadiah \& Zach, 2016), travel desires and visitor personalities in terms of whether they are introverts "go to feel" or extroverts "go to see" (Festila \& Müller, 2017). Despite these various debates, commonly established dimensions that form the Airbnb experience are "economic benefits/cheaper price” (Guttentag \& Smith, 2017; Young, Corsun, \& Xie, 2017), “location” (Tussyadiah \& Zach, 2016), 
"household amenities" (Guttentag, 2015), “cleanliness" (Bridges \& Vásquez, 2016), "authentic experience/host-guest interaction" (Festila \& Müller, 2017), and spending time in local neighbourhoods (Tussyadiah \& Zach, 2016; Yannopoulou, 2013).

\section{User experience of hotel}

Attributes that contribute to customers' hotel selection, purchase, quality of experience and satisfaction are probably one of the most researched areas in hospitality research. A number of studies have tried to develop an extensive list of hotel attributes that reflect customers' expectation and determine their purchase decision (e.g., Albayrak \& Caber, 2015; Alcantara, Artacho, Martinez \& Canpos, 2013; Ariffin \& Maghzi, 2012; Callan \& Bowman, 2000; Crnojevac, Gugic \& Karlovcan, 2010; Dolnicar \& Otter, 2003). Attributes influencing customers hotel selection include hotel brand and image, price, a hotel's physical features (such as size, architecture, decoration, cleanliness, facilities, amenitites, design, space), room features (such as space, furnishing), services, security, food and beverage provision, and location (Dolnicar \& Otter, 2003). Although the list of attributes may take priority over others, researchers tend to agree that customers select hotels based on services, location, room, price or value for money, food and beverage, hotel image, security and hotel marketing (e.g., Crnojevac et al., 2010; Dolnicar \& Otter, 2003; Liu, Law, Rong, Li \& Hall, 2013).

Given the extensive list of hotel attributes that influnce customer decision making and satisfaction, researchers have endeavoured to categorise the attributes to aid systematic understanding and provide a level of ease for practionners to evaluate. Walls (2013) categorised hotel attributes into two main clusters, namely "physical envrionment" and "human interactions". Physical environment includes design, property upkeep, ambience (cleanliness, comfort, elegance, landscaping, security and safety, lighting), space and function (architectural layout, space and maintenance, furnishings, socially engaging enviroment, equipement), signs, symbols and artefacts (quality of materials, signage, and personal artefacts). Human interactions include the attitude of staff (happy, friendly, accommodating, courteours, respectful, nurture guest rapport), professional behaviour (efficient, knowledgable) and proactive services. Human factors are an important attribute for hotel experiences as they provide a sense of privacy and home-like feelings for customers, and also the quality of service provided by friendly and helpful staff from room and concierge service can give guests a personal touch (e.g., Aggett, 2007; McIntosh \& Siggs, 2005).

With the emergence of Airbnb as an alternative accommodation option, hotels are keen to understand the attributes that make Airbnb so popular with visitors. Knwoledge of the similarities and differences can help hotels to develop effective strategies to differentiate themselves from Airbnb in order to better harness their competitive advantage. Two studies have so far presented exploratory findings in this line of research. Belarmino et al. (2017) revealed that Airbnb users valued the local interactions and experiences that occur in host neighbourhoods while hotel guests valued room amenities and food and beverage more. Mody, Suess, and Lehto (2017) surveyed 630 customers who 
stayed in either Aibrnb or hotel accomadation. Their findings indicate that Airbnb outperformed hotels in the provision of accommodation experiences as it relates to serendipity (enjoying spontanous interactions and events), localness, communitas and personalization. The two studies point to the fact that the main differences between Airbnb and hotels lay in the 'host in Airbnb/staff in hotels' and 'guest' interaction and 'ambience' between both, while other attributes tend to be similar. However, existing comparisons between the two accommodation types remain vague as they largely focus on general concepts from a macro perspective (e.g. host in general) without providing sufficient detail on concepts from the micro perspective (e.g. flexibility of the host). It is argued that a more nuanced understanding of the Airbnb experience is required that takes into account both the macro and micro perspectives. To address these issues and provide a more coherent understanding, this study analyses a big data set of online review comments from Airbnb users in Sydney to unpack the attributes of the Airbnb experience.

\section{Big data analytics}

The increasing realization of data and analytics as the core for business has become increasingly prevalent as we enter an age of "big data". Big data is commonly defined through three distinctive features - volume, velocity and variety. Volumes describes the quantity of the data, velocity refers to the speed of data processing, and variety refers to the type of the data. The massive amount and varieties of data challenge the conventional approach to data analyses, as the amount and structure of the data are well beyond human manual processing techniques (George, Osinga, Lavie, \& Scott, 2016). The concept of big data has gained popularity in the business world in the last five years as it recognizes its ability to generate better answers to existing and new questions (Frizzo-Barker, Chow-White, Mozafari, \& Ha, 2016; George et al., 2016). In particular, with big data analytics, methodologically researchers can work backward, starting with the data collection followed by analysis and gaining insights (Cheng, 2017). However, the tourism and hospitality field has taken some time to embrace 'big data' with only a few relevant articles recently published using this approach (Fuchs, Höpken, \& Lexhagen, 2014; Xiang, Schwartz, Gerdes, \& Uysal, 2015).

One of the main areas that has drawn researcher's attention is social media data as it offers the public a way of read-read to read-write (Piryani, Madhavi, \& Singh, 2017). Analysing social media posts presents an unrivaled breath of data to drive insights into a range of tourism and hospitality phenomena. Researchers have started to use big data to assess guests' hotel experiences (Xiang et al., 2015) and understand knowledge sharing structure of TripAdvisor (Edwards, Cheng, Wong, Zhang, \& $\mathrm{Wu}, 2017)$. However, because social media is usually unstructured and contains more than numerical data, it has raised concerns over the effectiveness of traditional research processes and a need for advanced methods to be able to systmatically and effectively tap its potential (Lu \& Stepchenkova, 2015). Edwards et al. (2017, p. 693) suggests that when approaching big social media data, "an initial understanding of the data structure and content, a cautious data cleaning process, a multidisciplinary approach beyond simple text and statistical analysis and a clear and visual representation of the data" 
is needed. This involves considerable input from the researcher(s) who need to interactively and iteratively engage with algorithms. Therefore, as this paper deals with a vast amount of unstructured Airbnb review comments, the research process employed to deal with this issue is clearly outlined below. It highlights each step involved in order to assist other researchers looking to replicate this type of method.

\section{Research Design \\ Data collection}

Research has already confirmed the importance and usefulness of online review comments to identity users' behaviours and its links to firm's performance and social practices creating unique insights for both researchers and practitioners (He, Zha, \& Li, 2013; Small \& Harris, 2014; Tussyadiah \& Zach, 2016). In particular, review comments mirror "the way consumers describe, relive, reconstruct, and share their experience" (Xiang et al., 2015, p. 44), which are considered important to consumers. Following the recommendation of Xiang et al. (2015), this study utilized a "big data" set of review comments from Sydney to avoid the "inference" issues often associated with a small sample of online review data. The reason for selecting Sydney as the research setting is that it has enjoyed a dramatic growth in Airbnb with 23,615 listings by December 2016, which is ranked the fourth most popular destination for Airbnb in the world (Stuart, 2017) (Figure 1). By doing so, this study expands the geographic scope of research on the sharing economy beyond those typically conducted on settings in Europe and USA.

The data set was obtained from the Inside Airbnb website with a total of 181,263 review comments (http://insideairbnb.com/). The review comments are publicly accessible. No ethical clearance was needed, as Kozinets (2010, p. 151) notes, the "download of existing posts does not strictly qualify as human subjects research. It is only where interaction or intervention occurs that consent is required" (Hookway, 2008). The software program OpenRefine was used to clean the non-English data from the set leaving a total of 170,124 comments in English. The data analysis was performed by the text mining software Leximancer. Leximancer has been used in more than 1,200 publications (since January 2018, see http://info.leximancer.com/) and in various areas of research both within and outside tourism (Cheng, 2016; Darcy \& Pegg, 2011; Jin \& Wang, 2016; Sun, Zhang, \& Ryan, 2015). More recently, research demonstrates that Leximancer provides objective and rigorous results while reducing pre-concieved bias that may be associated with manual analysis (Nunez-Mir, Iannone, Pijanowski, Kong, \& Fei, 2016). A detailed explanation on Leximancer's algorithm can be found in the work of Smith and Humphreys (2006). Leximancer produces a heat map as the end result, where themes are colour-coded (hot - cold) to indicate themes' prominence, where concepts that have strong semantic meanings are clustered together. 


\section{Data analysis}

Four stages were involved in the data analysis. In the first stage, text mining was performed to identity the semantic and relational insights of the review comments. This was performed through unsupervised learning. In the second stage, previously identified themes and concepts were compared with existing attributes reported in the hotel literature. This comparison helped to derive additional insights by identifying the similarities and differences. In the third stage, when the hotel attributes were not sufficient to be identified in the first stage of analysis, supervised learning of these attributes was performed. For example, in the first around of analysis with unsupervised learning, price did not appear as a theme or a concept. As such, a defined concept "price" was used to perform specific concept extraction. For the concept "price", its initial thesaurus only contains the words (price and money), as such these words are fairly unambiguously to identity the new concepts in the text. As Leximancer automatically extracts additional terms through its thesaurus learning phase, it is not necessary to know all the relevant words (Leximancer, 2011). As a result, the supervised learning identified price with a connectivity score of less than $2 \%$. This indicates that price was not treated as important as other attributes when evaluating Airbnb experiences. This also supports the fact that the absence of a concept in Leximancer can indicate that "important concepts fail to occur sufficiently frequently within the text to be identified and associated with other concepts" (Liesch, Håkanson, McGaughey, Middleton, \& Cretchley, 2011, p. 25).

In the last stage, sentiment analysis was utilized to identify users' positive and negative attitude towards the attributes identified earlier. Sentiment analysis is a type of text mining that measures people's 'sentiments' on whether they are positive or negative toward a particular topic through extracting and analyzing people's subjective information (Khan, Atique \& Thakare, 2015; Ma, Cheng \& Hsiao, 2018). In the big data space, researchers are interested in people's sentiment toward each identified topic as its understanding can be used to monitor customers' experience toward particular services or products in order to improve customer experiences (He, Wu, Yan, Akula, \& Shen, 2015). In this study, the sentiment analysis produced a direct overview of probability of a Airbnb user experience concept being mentioned in a positive and negative context (Leximancer, 2011). The sentiment analysis was performed using a lexicon plus a machine learning hybrid method in Leximancer. Leximancer contains English language lexicon lists of positive and negative sentiments, plus negation items. The machine learning hybrid first removes obvious outlier terms from the lexicon based on word cooccurrence statistics and then continues on to find other related terms from the data through thesaurus learning. A list of sentiment seeds is provided in Appendix 1. To facilitate micro level insights of the relevant themes and concepts, direct positive and negative quotes are provided in the findings, which are not amended for grammatical and/or typographical errors. As this paper aims to provide comparative insights of the attributes between Airbnb and hotels, only salient attributes are introduced in detail. A detailed hit score of each attribute under their respective themes is provided in Appendix 2. 


\section{Findings}

\section{Basic information of the data}

On average, the length of each review entry obtained from Airbnb was 58 words ( $S T D=46.96)$. Figure 2 illustrates the distribution of word length, indicating a mode of 34 words as the highest number of review comments $(2,340)$ and $75.9 \%$ of the review comments contain between 4 to 77 words. Only very a small percent $(0.12 \%)$ of review comments contained a word length beyond 400 .

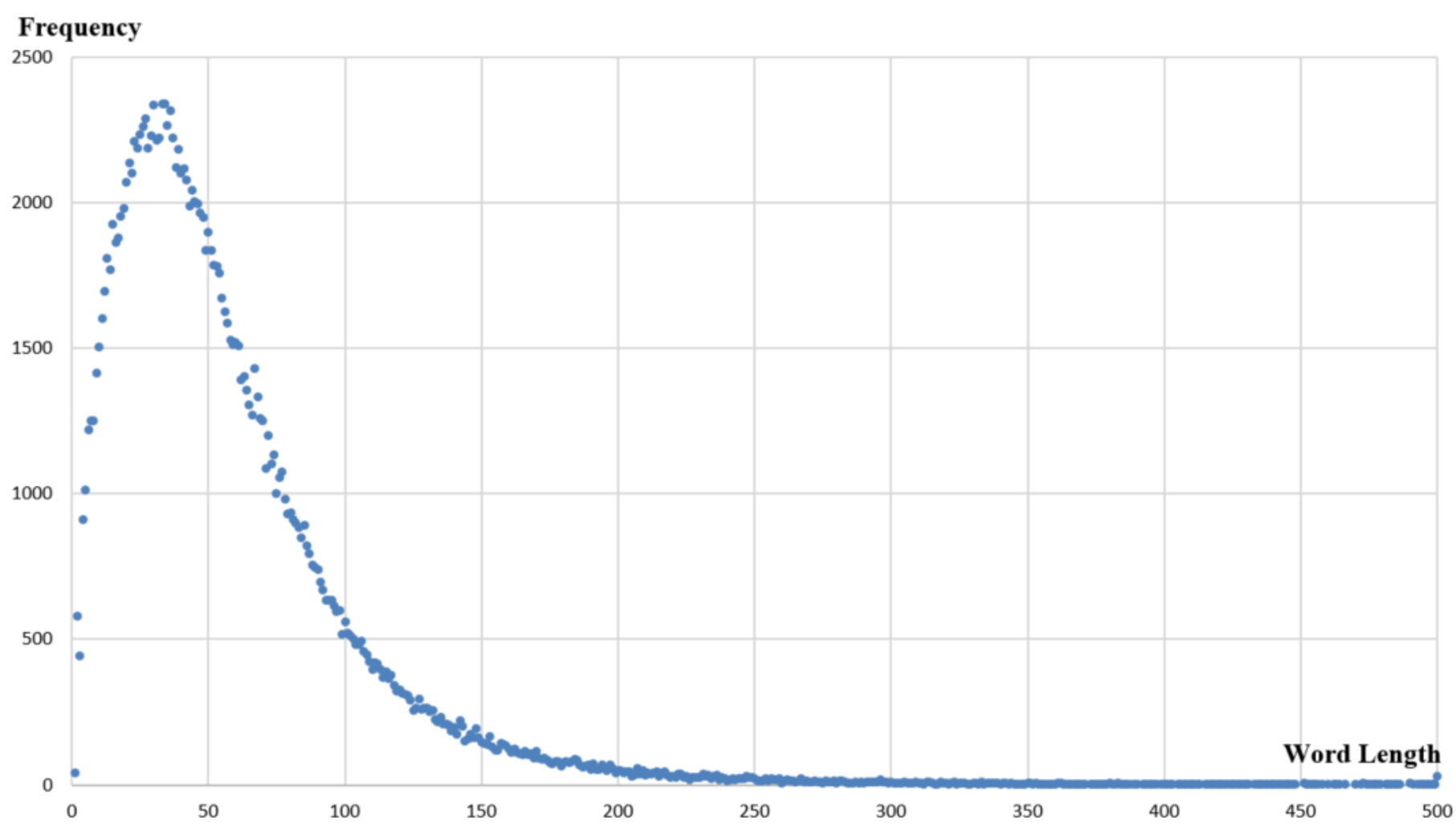

Figure 2: Distribution of the word length

\section{Text-mining results}

Four major topics emerged within the review comments including -'location' (100\%), 'amenities' (81\%), 'host' (70\%) and 'recommendation' (18\%) (by order of importance) (Table 1). 'Host' emerged as an important theme, which has implications on the role of the 'host-guest encounter' and 'services' play in Airbnb users' experience. Importantly, while 'recommend' appeared as a theme, it was not regarded as an attribute but the reference to 'recommend' was an outcome of the other three themes. In particular, Figure 3 shows that concepts within the themes 'location' and 'host' had greater influence over Airbnb users' recommendations. To further identify the relationship between "recommend" and other concepts, likelihood scores were used. The likelihood scores presented the conditional probability of the text segments with a concept that also contains another concept (Leximancer, 2011). Table 2 shows that while recommendation of a place in Airbnb was apparently an outcome of a positive experience, in the Airbnb context, 'location' (city, beach, short, transport, nearby, shopping, bus), 'a good place for family', 'friendly and helpful host', and 'nice home' (bed, water, bathroom) could lead 
to a "recommend". For example, 'a good place for family' had a likelihood score of $12 \%$, indicating that $12 \%$ of the text segments with the term 'family' containing 'recommend' (concept: favourable). Additionally, users' experience with Airbnb and hotels shared some common attributes. This is because Airbnb users tend to use the criteria of traditional hotels to evaluate their Airbnb experience as the quote below illustrates:

The accommodation was as clean and carefully appointed as any five star hotel that I've stayed at over the years - beautiful linens, special in-room coffee/tea service and daily fresh milk, fresh daily water set out on a lovely silver tray with glassware, fine furnishings, quality towels and absolutely gorgeous bath products and toiletries.

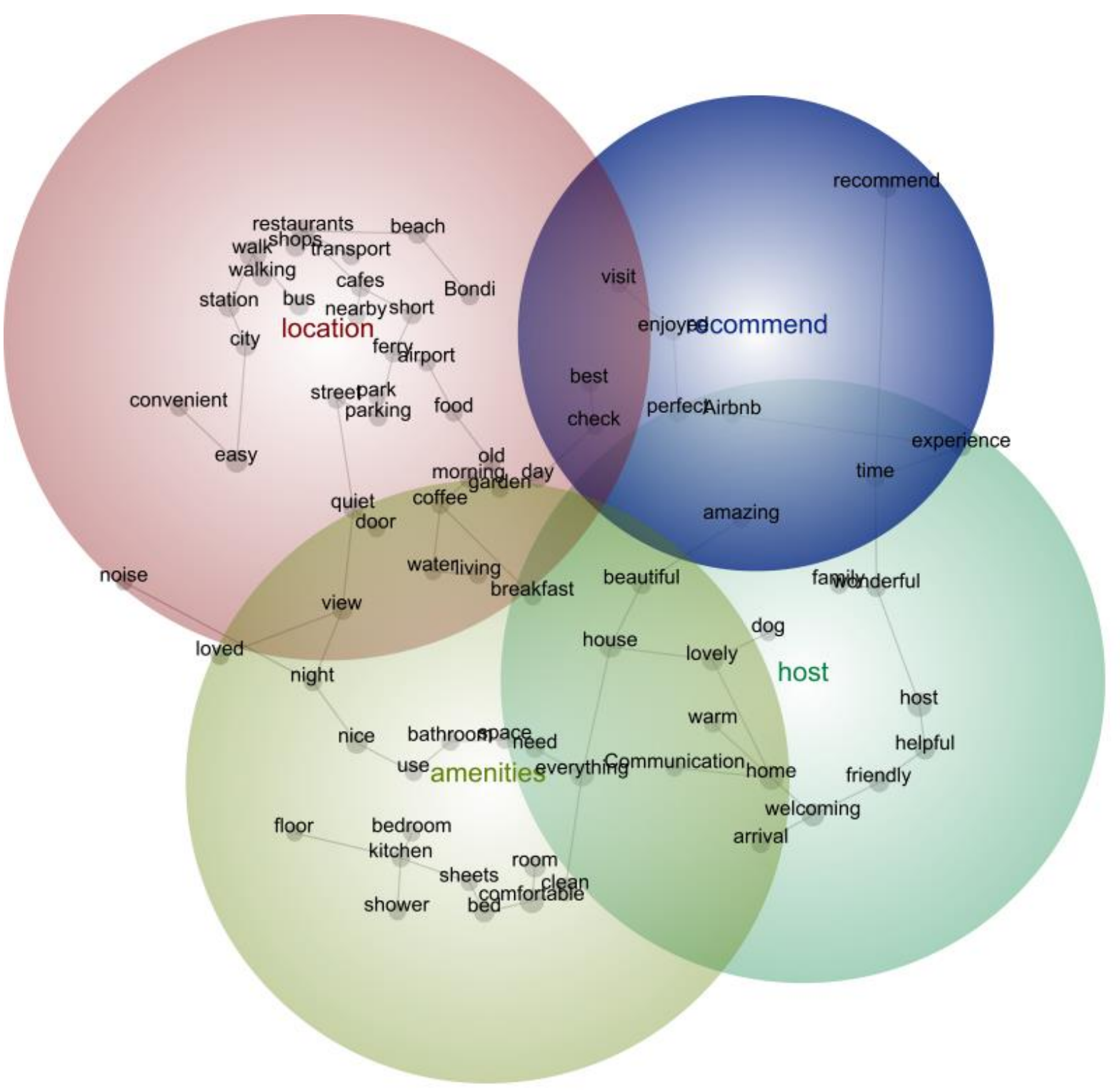

Figure 3: Conceptual map of the themes and concepts 
Table 1: Connectivity score* of each theme

\begin{tabular}{|l|l|l|l|l|}
\hline Theme & Location & Amenities & Host & Recommend \\
\hline $\begin{array}{l}\text { Connectivity } \\
\text { score }\end{array}$ & $100 \%$ (Red) & $\begin{array}{l}79 \%(\text { Light } \\
\text { green) }\end{array}$ & $\begin{array}{l}70 \%(\text { Dark } \\
\text { green) }\end{array}$ & $21 \%$ (Blue) \\
\hline
\end{tabular}

* The connectivity scores indicate the relative importance of the themes (the most important is the top Theme at $100 \%$ ).

Table 2: Individual concept's likelihood scores related to recommend

\begin{tabular}{|c|c|c|c|c|c|}
\hline Concept & Count & Likelihood & Concept & Count & Likelihood \\
\hline visit & 1277 & $16 \%$ & parking & 542 & $6 \%$ \\
\hline family & 1431 & $12 \%$ & room & 1909 & $6 \%$ \\
\hline experience & 2319 & $12 \%$ & space & 719 & $6 \%$ \\
\hline city & 2207 & $9 \%$ & bus & 944 & $6 \%$ \\
\hline time & 2687 & $9 \%$ & breakfast & 526 & $6 \%$ \\
\hline host & 5105 & $9 \%$ & station & 1319 & $6 \%$ \\
\hline short & 1132 & $8 \%$ & ferry & 281 & $6 \%$ \\
\hline beach & 1846 & $8 \%$ & morning & 355 & $6 \%$ \\
\hline $\operatorname{dog}$ & 229 & $8 \%$ & view & 1229 & $6 \%$ \\
\hline house & 2617 & $8 \%$ & check & 450 & $6 \%$ \\
\hline home & 3783 & $7 \%$ & living & 290 & $6 \%$ \\
\hline use & 491 & $7 \%$ & coffee & 507 & $5 \%$ \\
\hline quiet & 1144 & $7 \%$ & street & 451 & $5 \%$ \\
\hline transport & 845 & $7 \%$ & bed & 994 & $5 \%$ \\
\hline cafes & 737 & $7 \%$ & park & 216 & $5 \%$ \\
\hline airport & 452 & $7 \%$ & bedroom & 294 & $5 \%$ \\
\hline need & 1060 & $7 \%$ & water & 183 & $4 \%$ \\
\hline day & 698 & $7 \%$ & door & 217 & $4 \%$ \\
\hline restaurants & 2287 & $6 \%$ & bathroom & 473 & $4 \%$ \\
\hline night & 708 & $6 \%$ & arrival & 751 & $4 \%$ \\
\hline walking & 898 & $6 \%$ & garden & 177 & $4 \%$ \\
\hline nearby & 402 & $6 \%$ & floor & 109 & $4 \%$ \\
\hline food & 373 & $6 \%$ & kitchen & 543 & $4 \%$ \\
\hline walk & 3452 & $6 \%$ & sheets & 244 & $4 \%$ \\
\hline everything & 3016 & $6 \%$ & shower & 160 & $4 \%$ \\
\hline shops & 1219 & $6 \%$ & & & \\
\hline
\end{tabular}

\section{Sentiment analysis results}

The results of the sentiment analysis indicate that Sydney Airbnb users were overwhelmingly positive about many aspects of their experience (Table 3). For example, the likelihood score of $66 \%$ for host means that $66 \%$ of the text segments with the term host contains positive sentiments (concept: favourable). In contrast, the topic areas that consistently received negative sentiments were noise, floor, 
shower, parking, and door (host only receives a negative likelihood score of $1 \%$ ). These support the literature that Airbnb comments have positivity bias towards the hosts with Airbnb's reciprocal rating system. While Airbnb's comments are largely positive, a closer look at the conditional count of each concepts reveals that there are the areas where negative sentiment occurred, indicating an opportunity for Airbnb hosts to address these areas through rectifying any maintenance issues or setting realistic expectations (e.g. noise occurs in big cities). In addition, concepts related to city environment (e.g., transport, restaurants, city, shops, cafes, garden, station, and airport) enjoy highly positive scores and very low negative scores, indicating that Sydney's general environment could play a role in forming Airbnb user's positive experience.

Table 3: Likelihood scores of sentiment analysis

\begin{tabular}{|c|c|c|c|c|c|}
\hline Positive & & & Negative & & \\
\hline Concept & Count & Likelihood & Concept & Count & Likelihood \\
\hline host & 38485 & $66 \%$ & noise & 316 & $7 \%$ \\
\hline transport & 7669 & $61 \%$ & floor & 162 & $6 \%$ \\
\hline view & 12502 & $57 \%$ & shower & 242 & $6 \%$ \\
\hline restaurants & 19990 & $57 \%$ & parking & 424 & $5 \%$ \\
\hline city & 13216 & $56 \%$ & door & 207 & $4 \%$ \\
\hline shops & 11051 & $56 \%$ & water & 165 & $4 \%$ \\
\hline house & 19284 & $56 \%$ & night & 413 & $4 \%$ \\
\hline $\operatorname{dog}$ & 1654 & $55 \%$ & morning & 206 & $3 \%$ \\
\hline cafes & 6081 & $54 \%$ & bathroom & 338 & $3 \%$ \\
\hline garden & 2329 & $54 \%$ & sheets & 194 & $3 \%$ \\
\hline station & 12227 & $54 \%$ & bedroom & 190 & $3 \%$ \\
\hline beach & 12259 & $53 \%$ & day & 321 & $3 \%$ \\
\hline arrival & 9263 & $53 \%$ & use & 202 & $3 \%$ \\
\hline walk & 29444 & $53 \%$ & check & 225 & $3 \%$ \\
\hline home & 26773 & $52 \%$ & arrival & 482 & $3 \%$ \\
\hline clean & 26420 & $52 \%$ & kitchen & 335 & $2 \%$ \\
\hline experience & 9953 & $52 \%$ & street & 218 & $2 \%$ \\
\hline nearby & 3261 & $52 \%$ & park & 106 & $2 \%$ \\
\hline bus & 8297 & $52 \%$ & experience & 419 & $2 \%$ \\
\hline breakfast & 4585 & $51 \%$ & airport & 146 & $2 \%$ \\
\hline family & 5920 & $50 \%$ & bed & 394 & $2 \%$ \\
\hline room & 15908 & $50 \%$ & time & 554 & $2 \%$ \\
\hline time & 14971 & $50 \%$ & room & 525 & $2 \%$ \\
\hline ferry & 2418 & $50 \%$ & space & 190 & $2 \%$ \\
\hline short & 6926 & $49 \%$ & nearby & 96 & $2 \%$ \\
\hline airport & 3335 & $48 \%$ & $\operatorname{dog}$ & 45 & $2 \%$ \\
\hline food & 2879 & $48 \%$ & need & 231 & $1 \%$ \\
\hline coffee & 4553 & $48 \%$ & house & 487 & $1 \%$ \\
\hline
\end{tabular}




\begin{tabular}{|c|c|c|c|c|c|}
\hline check & 3827 & $48 \%$ & family & 153 & $1 \%$ \\
\hline space & 5584 & $47 \%$ & host & 759 & $1 \%$ \\
\hline park & 2001 & $46 \%$ & food & 76 & $1 \%$ \\
\hline bed & 8959 & $45 \%$ & home & 604 & $1 \%$ \\
\hline street & 3880 & $44 \%$ & transport & 145 & $1 \%$ \\
\hline need & 7035 & $43 \%$ & walking & 158 & $1 \%$ \\
\hline shower & 1847 & $43 \%$ & bus & 177 & $1 \%$ \\
\hline kitchen & 5738 & $43 \%$ & coffee & 103 & $1 \%$ \\
\hline water & 1750 & $43 \%$ & garden & 47 & $1 \%$ \\
\hline bathroom & 4581 & $43 \%$ & station & 241 & $1 \%$ \\
\hline bedroom & 2610 & $42 \%$ & recommend & 449 & $1 \%$ \\
\hline use & 3023 & $42 \%$ & city & 245 & $1 \%$ \\
\hline night & 4560 & $41 \%$ & visit & 79 & $1 \%$ \\
\hline morning & 2594 & $41 \%$ & breakfast & 87 & $1 \%$ \\
\hline visit & 3179 & $41 \%$ & ferry & 44 & $1 \%$ \\
\hline day & 4372 & $41 \%$ & view & 194 & $1 \%$ \\
\hline living & 2130 & $41 \%$ & beach & 203 & $1 \%$ \\
\hline parking & 3519 & $39 \%$ & cafes & 89 & $1 \%$ \\
\hline sheets & 2378 & $38 \%$ & restaurants & 275 & $1 \%$ \\
\hline door & 1776 & $36 \%$ & shops & 152 & $1 \%$ \\
\hline floor & 856 & $32 \%$ & & & \\
\hline
\end{tabular}

\section{Themes}

\section{Location}

The first theme (shown in Fig. 3) is location (red) and describes the convenience of the accommodation to major tourist attractions, transport or points of interests (e.g. shops, cafes). Concepts include geographical location to restaurants, transport, shops, attractions and parking, as well as the safety of the location. Despite the fact that some guests reported negative experiences associated with location (parking space, noise at night, and unsafe surroundings), they generally treated this as minor as long as they found the location to be convenient.

\section{Positive}

The location is within easy reach of shopping, restaurants, public transport to the city (bus and ferry), not too far from the beautiful Balmoral beach and close to beautiful harbour side walking tracks.

I really needed to stay somewhere in Collaroy due to my wife attending a conference at Collaroy centre, so the location of the cottage was perfect from that perspective. It is also close to a bus stop that has frequent buses going to Wynyard Station, or Manly Wharf which made it easy for us to travel around Sydney.

\section{Negative}

The only thing that could be seen as negative is the noise in the bedroom as it is right on a main street, however that is to be expected when you are right in the heart of Sydney. 
I should note that if you have a car, you can't park in the building and the surrounding area can be both difficult and expensive. But I'm assuming most folk on holiday would be car free and way, and with the train station and bus stops practically next door, transportation around Sydney is a breeze!

Just be aware though that although Colleen's place is very safe and beautiful, you may have to go through Kings Cross to get to the city. But most people don't find this a problem and I certainly felt safe.

\section{Amenities}

The second theme is amenities of the accommodation, including facilities of the place, the room and the night time environment.

\section{Facilities}

Facilities deal with the environment of the house, including the general house environment and accessories such as garden, pool, and balcony as well as facilities for daily use. This concept is similar to the 'physical envrionment' of hotels as noted Walls (2013) paper. Review comments indicate that Airbnb users valued the feelings of being at home that are attached to those facilities. However, negative reviews did occur when the facilities aspect were not accurate to what was described in the host's Airbnb page and up to a convenient standard for the stay.

\section{Positive}

There was a table/chairs and sofa in front of the TV. Lots of towels in the bathroom, nice powerful shower and May supplied lots of toilet tissues, tooth brushes, BIG bottles of shampoo, conditioner, shower gel and face and body lotion, even face wipes, very impressed. The kitchen has a good size fridge, microwave, kettle, iron, washing machine basically everything you need and the entire place was very clean and we were offered a free house clean after the first several days.

- the flat was very comfortable with very well equipped kitchen - we enjoyed also the big screen smart TV - capable of playing back also movies off the USB HDD

- the flat offers also washing machine and dryer option

- would prefer wooden floors over carpets, nevertheless overall experience was great and let us feel like being home

\section{Negative}

The listing was accurate except that I wasn't informed that the washing machine had blown up (which was a big problem and inconvenience for me). I really felt the terrace could have been cleaned so that it was usable - let's just say it did not look like this picture!

Unfortunately, it's somewhat run down and in need of maintenance: the stove's gas rings don't all work and the doors are starting to fall off; the couch is stained and torn with legs falling off; there were broken lamps and various missing lightbulbs; a lot of non-working junk sitting around too.

While food and drinks are generally not expected in the Airbnb experience, provision of these can be interpreted by Airbnb guests as a delight. 
Every little detail was thought of right down to bottles of water at your bedside. We only stayed there for one night but wish we could have stayed a lot longer.

\section{Room}

The cluster of concepts associated with 'room' describes the room environment, such as the space, bed, room design, cleanliness and decoration. The room is also connected to the theme 'night', referring to the night environment in and around the hosts' place. The theme 'night' is mainly concerned with the quality of sleep, privacy of the place, and the night view. Quality of sleep and privacy of the room is considered important in this theme, which is often associated with noise, while the privacy of the room refers to the fact that the guests will not be disturbed by the hosts, people who stay together and the crowdedness of the location.

\section{Positive}

My partner and i are very private people when it comes to choosing a place to stay and although this place is attached to Andrea's property, it was perfectly private - we did not run into anyone the entire time other than the day we collected the keys.

\section{Negative}

We stayed here for over 40 nights, unfortunately there was apartments and condos being built at the early stages so there was construction noise from $7 \mathrm{am}$ till $5 \mathrm{pm}$ and Saturdays $7 \mathrm{am}$ until $12 \mathrm{pm}$.

\section{Host}

The theme 'host' covers a variety of concepts about the role that the host plays in facilitating an Airbnb experience. The main concepts are helpfulness, flexibility, and communication of the hosts and the animals that Airbnb hosts have.

\section{Helpfulness of the host}

Helpfulness of the host not only refers to the help offered by the host with the accommodation but also help with loss of personal items for example. This indicates that the level of help provided by Airbnb owners could be extremely helpful. However, the intensity and extent of host help could be significantly different from one property (e.g. host is completely helpless) to the next (e.g. host is extremely helpful).

\section{Positive}

The Host: Very kind and excellent host. Robert has a unique and interesting collection of antiques and the story of the house is amazing. He was very kind to assist with the luggage up to the room and provided very sensible advice and suggestions about local travel and housing in Sydney. Some very interesting conversations about AU politics too in the midst. Robert was very kind to allow me to use the ironing board and iron when needed and even offered the use of the washing machine 
I lost my prescription glasses in the Bondi waves, and Sarah worked diligently with me to find and contact local optometrists AND optometrists in Melbourne, our next destination. I was able to secure replacement prescription glasses within 48 hours, which I could not have done without Sarah.

\section{Negative}

but I made a point on this review because also the host accused me of drinking her wine and charging me for the electrics going off when I left the place drinking my bowl with cold milk... it isn't my problem when the electric blows after I leave. Also was accused of taking out a plug for a wine fridge... hadn't touched anything and I believe I am a very good guest.

I understand there are risks around knowing what you are going to get with air bnb, our bad luck this time I guess. Perhaps we just struck the hosts on an off day. But if you are going to open up your home to guests, I think you have to show a reasonable amount of consideration for their needs. A very disappointing experience.

\section{The flexibility of the host}

The flexibility of the host refers to their willingness to accommodate the requests of the guests, particularly with check-in and check-out times.

\section{Positive}

All communication was friendly and timely. Merela was very flexible with her check in and check out times which we really appreciated!

\section{Negative}

it's like staying in a hotel, but with really crap service. checking in is strictly to their time schedule, no flexibility. And don't try and change your dates, they deny them. I will now have to follow up with AirBNB to get a refund for the dates I didn't stay and notified them for.

\section{Communication}

The concept "communication" is also highlighted by guests. The review comments show that host and guest communications involve different stages (pre, onsite, and post), for different purposes (checkin/out, facilities, help), and via different modes (online, face-to-face). One feature of Airbnb host and guest communication is the pre-written instructions by host/owner, which is published online or disseminated to guests on arrival. The results indicate that Airbnb users are happy to read these instructions and they don't feel it is a hassle. However, guests do voice their concerns when they feel that the instructions are too rigid.

\section{Positive}

Our host had left a clear booklet with instructions for using appliances, security details, do's and don'ts within apartment which were very useful and easy to follow plus information regarding parking and the locality. We felt reassured knowing we could contact our host or a family member had we encountered any problems. Also a personal touch of Christmas card and chocolates very thoughful. 


\section{Negative}

Me \& my stayed here for a week whilst in Sydney doing a course, we were barely there but when we were it nothing but a bad experience, bad communication from host made us wait hours on end till check in, power would trip out resulted in us searching around in the dark outside trying to find the circuit board.

\section{Pre-arrival communication}

As Airbnb shifts the online experience to face-to-face transactions with strangers, good pre-arrival communication can help guests to relieve their initial anxieties and to build up trust.

\section{Positive}

Before the trip we got detailed and clear information about the house and surroundings. Emma was very welcoming in her communication and there was no unanswered questions before we started our trip.

\section{Negative}

Central location and nice apartment, as advertised in listing, but had frustrating experience with host, including poor communication and response time. Specifically, (1) waited an hour to obtain keys to get into apt., despite specific instructions and timing agreed to the night prior; (2) after asking how to connect to wifi and allow people through security door when they call up to apt. (host failed to provide instructions for both beforehand or in apt.), host belatedly responded to first question and never responded to second;

\section{Check in and out, during-the-stay communication}

As Airbnb hosts are not available 24 hours to answer enquiries and solve unexpected problems, communications about check in and outs are important for guests in order to allay any confusion.

\section{Positive}

Although we did not meet Charlotte or Chris during our, communicating with them was easy. They provided thorough and clear check-in/out instructions. Their guidebook served as a useful resource (recommendations for eateries, walking/jogging routes from the apartment, tour options, train map, etc).

\section{Negative}

Well...there was a couple of situations with the facility, all of which I was able to care for. Adam did respond when he could which means basically: during office hour. So just be aware that if something happens and that you need assistance "right away" out of the office hours it might not happened "right away" you might have to wait the next morning for a response, that's all.

(3) when wifi instructions he gave me didn't work, I had no way to contact him, so cleaning lady (place had not yet been cleaned when we arrived, and actual cleaning when completed 
was subpar) had to reach him via her mobile to explain the problem; and (4) he didn't respond with resolution for several hours, so had no wifi on first of only three days in apt.

\section{Animals (dogs, cats)}

Animals refer to animals in a host's place, as guests generally comment on the friendliness of animals which reflects on a host's hospitality but unfriendly animals can also negatively influence the overall experience of the guest. It is important to note that the concept of animals is one of the differences between Airbnb and a hotel stay, as most hotels would not allow guests to keep animals inside their room.

\section{Positive}

Though I haven't meet her, Felicity with her very cute dog welcomed us on our arrival. What an awesome stay and most importantly we enjoyed our privacy not to forget taking care of her lovely plants :D I will definitely stay in this place again instead of a hotel, affordable yet cozy.

\section{Negative}

Loulias dog was barking and trying to bite us and she didnt do anything to stop it so it wasnt so nice.

\section{Discussion and implications}

The research identified that Airbnb guests generally use the same accommodation attributes associated with hotel stays to assess their experience, while the order of importance of these attributes might be different. Three main attributes, location, amenities and host form the majority of content of the written comments on Airbnb users' online review portal. Table 4 provides a summary of notable findings from the research which are compared to the extant literature. With regards to 'host/hotel staff and guest encounters', the role of the host in the Airbnb context ranges from being very helpful to not helpful at all. The Airbnb experience can be more polarised and less predictable for the guest than hotel operations and services, which are more standardised, leading to both good and bad experiences. Although hosts play a more important role than hotel staff in what normally occurs in hotel settings, the data from this research provided little evidence for the highly sought-after authentic tourist-host interactions as indicated by the literature. The host's role is perhaps that of a facilitator rather than a guest-host social relationship builder. The topic warrants more exploration. As Airbnb shifts the service delivery process from professional providers to individual host (Tussyadiah \& Zach, 2016), it raises the question as to how we refine the notion of professionalism in the context of the sharing economy.

Further, the flexibility associated with Airbnb raises the question as to 'how frequent' and 'to what degree' can 'flexible arrangements' be catered for and whether hotels are able to offer the same level of 'flexibility' while maintaining a standardised service. This research shows that Airbnb guests are happy to read the instructions provided by their hosts, while in the hotel context, it is seldom seen that hotels have or need pre-stay instructions. If some hotels do provide this sort of information, to the best of our knowledge, there is no evidence suggesting that hotel guests readily read these. It seems that 
conventional hotel guests expect face-to-face communications and service, rather than communication/services delivered via the internet and/or guidebook. This is also related to the fact that Airbnb accommodation is not standardised, it being a home environment. It is important for the guests to read provided instructions in order to avoid any inconvenience.

The findings reveal the strategies in building up "trust" from Airbnb that are beyond the current literature (e.g. host's photos). This study points out that good communication plays an important role in building up the initial trust that could be built on the Airbnb accreditation system, as Airbnb entails a stranger-stranger transaction (Ert, Fleischer, \& Magen, 2015). In addition, guests highly value privacy and safety of stay, which are commonly guaranteed in hotels. 
Table 4: Similar and difference between Hotel and Airbnb user experience based on this research

\begin{tabular}{|c|c|c|c|c|c|}
\hline & Host & Location & $\begin{array}{c}\text { Professional skills \& } \\
\text { abilities }\end{array}$ & General amenities & Convenience \\
\hline $\begin{array}{l}\text { Existing } \\
\text { literature }\end{array}$ & $\begin{array}{l}\text { - Interaction with host } \\
\text { (Great emphasis on } \\
\text { feeling welcome and } \\
\text { meaningful interaction) } \\
\text { - Serendipity (spur of the } \\
\text { moment) }\end{array}$ & $\begin{array}{l}\text { - Location (proximity to } \\
\text { other place of interest, } \\
\text { e.g. restaurant, shops, } \\
\text { transportation, tourist } \\
\text { Attractions) } \\
\text { - Neighbourhood with } \\
\text { authentic and unique local } \\
\text { setting and belongingness }\end{array}$ & - Lack of standard & $\begin{array}{l}\text { - Cleanliness, noise, } \\
\text { space } \\
\text { - Extra materials, } \\
\text { such as home- } \\
\text { made guidebook } \\
\text { - Matching the } \\
\text { description }\end{array}$ & $\begin{array}{l}\text { - Waiting time } \\
\text { - Easy Check-in/out } \\
\text { - Price for value }\end{array}$ \\
\hline Airbnb & $\begin{array}{l}\text { - Helpfulness of the host } \\
\text { - The flexibility of the } \\
\text { host } \\
\text { - Communication } \\
\text { between the host and } \\
\text { guest during pre-arrival } \\
\text { and during the stay stage } \\
\text { - Host's name are } \\
\text { mentioned carrying } \\
\text { personal touch }\end{array}$ & Same & $\begin{array}{l}\text { - Full of surprises in terms } \\
\text { of the support from the } \\
\text { hosts } \\
\text { - Notion of } \\
\text { professionalism } \\
\text { - Provision of } \\
\text { food/beverage is a bonus }\end{array}$ & $\begin{array}{l}\text { - Sense of privacy } \\
\text { and safety } \\
\text { - The existence of } \\
\text { animals }\end{array}$ & $\begin{array}{l}\text { Same but this linked back to } \\
\text { the host's helpfulness and } \\
\text { communication }\end{array}$ \\
\hline
\end{tabular}

*Red indicates the findings from this research 
Apart from the comparisons between attributes the data indicates there are two major differences between Airbnb and hotels in term of review comment structure. Airbnb users tend to use the names of the owners in their comments (although mainly first names), whereas hotel guests seldom report the names of hotel staff in their review of their stays (Belarmino et al., 2017). The name carries a personal touch in this space. The other important point coming out from this research is that users can use reviews of host and their other information in Airbnb to trace each other, it creates a space for the curriculum vitae of hosts and guests. Thus, this adds to the evidence of why Airbnb reviews tend toward a positivity bias. This study provides empirical evidence into the positivity bias debate under Airbnb's non-anonymous communicative norms (Bridges \& Vásquez, 2016). It highlights the attributes that contribute to the positivity bias and also those that were reviewed negatively. By understanding these differences and similarities, existing hotel groups can better differentiate and highlight their service attributes to gain a competitive advantage. In particular, considering that Airbnb is in an ongoing process of refining its business model, this study is timely and suggests some practical implications as identified earlier. The attributes identified in this study can refine its rating items and also develop good practices and guidelines to assist Airbnb and its accommodation providers with improvements to its services. In summary, through an examination of both macro and micro perspectives, this study contributes to the sharing economy literature by providing a coherent and detailed understanding of user experiences as it relates to Airbnb.

From a methodological perspective, this paper contributes to recent research efforts on big data and social media (Zhou, Ye, Pearce, \& Wu, 2014). By systematically producing visual representations of large amounts of data, it adds further insight into analytical methods in this area (Edwards et al., 2017; Xiang et al., 2015). We support the evidence that human input plays an important role in effectively and efficiently deriving insights from big data. While machine learning is a useful tool it still needs theoretical reasoning in refining and interpreting the data for an interdisciplinary audience (Cheng \& Edwards, 2017). This is clearly demonstrated in our supervised learning process of the concept of price with the iteration of human input from the comparison with hotel literature (theoretical reasoning and supervised learning) and machine learning that automatically extracts additional terms through its thesaurus learning phase. In addition, while Leximancer offers an aerial view of big data by aggregating fragmented pieces of evidence into a cohesive visual representation, it did take the researchers considerable time and effort to interpret the findings, in particular gaining both macro and micro insights to make inferences. As such, data visualization will be a trend in big data analysis. Given the volume, velocity and variety of big data, traditional approaches (e.g. two-dimensional graphs) are unlikely to be sufficient to properly represent the data (McAbee, Landis, \& Burke, 2017). Thus, this research supports the observation of Cheng and Edwards (2017) that there is a need for tourism and 
hospitality researchers to become more adept in using and interpreting the visual representation of big data.

This study also opens up a number of future research avenues. First, combining regression analysis by incorporating other variables, such as rating and property descriptions would enhance the findings of this research and provide further insights. Second, through the data cleaning process, we noticed that a considerable number of users posted their comments in both their native language and in English. There is a need to examine why they do so. Third, comparisons between Airbnb and its counterparts in developing countries (e.g. Xiaozhu.com in China) will yield additional cross-cultural insights into user's experiences (Cheng, 2016). Fourth, while our research has identified more micro differences between Airbnb and hotels, at this stage, we do not have enough evidence to suggest to what degree the findings from the Sydney context could be generalised. However, the context of Sydney may play a role in influencing the attributes, as Airbnb user experiences would be undoubtedly affected by the general multicultural, vibrant, safe environment, ease of transport, and general household living standard of Sydney (Ironside, 2016; Son, 2005). These could partially contribute to the positivity comments identified in the sentiment analysis of this research. Thus, future comparative studies between different regions will be a useful next step forward, adding more evidence to the convergence/divergence debate of the sharing economy experience (Brochado, Troilo, \& Shah, 2017). Lastly, it has promising potential to differentiate review comments written by Airbnb users from different backgrounds, such as distinguishing Western users from Asian users, as well as users staying in a 'private' room from those renting an entire home, as these will generate additional insights from multiple perspectives. 


\section{References}

Aggett, M. (2007). What has influenced growth in the UK's boutique hotel sector? International Journal of Contemporary Hospitality Management, 19(2), 169-177. https://doi.org/10.1108/09596110710729274

Airbnb. (2017). About us. Retrieved from https://www.airbnb.com.au/about/about-us

Albayrak, T., \& Caber, M. (2015). Prioritisation of the hotel attributes according to their influence on satisfaction: A comparison of two techniques. Tourism Management, 46, 43-50. https://doi.org/10.1016/i.tourman.2014.06.009

Alcántara-Alcover, E., Artacho-Ramírez, M. Á., Martínez-Guillamón, N., \& Campos-Soriano, N. (2013). Purpose of stay and willingness to stay as dimensions to identify and evaluate hotel experiences. International Journal of Hospitality Management, 33, 357-365. https://doi.org/10.1016/j.ijhm.2012.10.006

Ariffin, A. A. M., \& Maghzi, A. (2012). A preliminary study on customer expectations of hotel hospitality: Influences of personal and hotel factors. International Journal of Hospitality Management, 31(1), 191-198. https://doi.org/10.1016/i.ijhm.2011.04.012

Belarmino, A., Whalen, E., Koh, Y., \& Bowen, J. T. (2017). Comparing guests' key attributes of peerto-peer accommodations and hotels: mixed-methods approach. Current Issues in Tourism, 17.

Bridges, J., \& Vásquez, C. (2016). If nearly all Airbnb reviews are positive, does that make them meaningless? Current Issues in Tourism, 1-19.

Brochado, A., Troilo, M., \& Shah, A. (2017). Airbnb customer experience: Evidence of convergence across three countries. Annals of Tourism Research, 63, 210-212.

Callan, R. J., \& Bowman, L. (2000). Selecting a hotel and determining salient quality attributes: a preliminary study of mature british travellers. The International Journal of Tourism Research; Bognor Regis, 2(2), 97.

Cheng, M. (2016). Sharing economy: A review and agenda for future research. International Journal of Hospitality Management, 57, 60-70. doi:http://dx.doi.org/10.1016/i.ijhm.2016.06.003

Cheng, M. (2017). “Big Data Management”, Fausto Pedro García Márquez and Benjamin Lev. Information Technology \& Tourism, 17(4), 455-456.

Cheng, M., \& Edwards, D. (2017). A comparative automated content analysis approach on the review of the sharing economy discourse in tourism and hospitality. Current Issues in Tourism, 1-15.

Crnojevac, I. H., Gugić, J., \& Karlovčan, S. (2010). eTourism: A comparison of online and offline bookings and the importance of hotel attributes. Journal of Information and Organizational Sciences, 34(1). Retrieved from https://doaj.org

Darcy, S., \& Pegg, S. (2011). Towards strategic intent: Perceptions of disability service provision amongst hotel accommodation managers. International Journal of Hospitality Management, $30(2), 468-476$.

Dolnicar, S., \& Otter, T. (2003). Which hotel attributes matter? A review of previous and a framework for future research. in Griffin, T \& Harris, R (eds.) Proceedings of the 9th Annual Conference of the Asia Pacific Tourism Association (APTA), University of Technology Sydney, $2003,1,176-188$.

Dredge, D., \& Gyimóthy, S. (2015). The collaborative economy and tourism: Critical perspectives, questionable claims and silenced voices. Tourism Recreation Research, 40(3), 286-302. doi:10.1080/02508281.2015.1086076 
Edelman, B. G., Luca, M., \& Svirsky, D. (2016). Racial Discrimination in the Sharing Economy: Evidence from a Field Experiment. Harvard Business School NOM Unit Working Paper(16069).

Edwards, D., Cheng, M., Wong, A., Zhang, J., \& Wu, Q. (2017). Ambassadors of Knowledge Sharing: Co-produced travel information through tourist-local social media exchange. International Journal of Contemporary Hospitality Management, 29(2), 690-708. doi:10.1108/IJCHM-102015-0607

Ert, E., Fleischer, A., \& Magen, N. (2015). Trust and Reputation in the Sharing Economy: The Role of Personal Photos in Airbnb. Available at SSRN 2624181.

Fang, B., Ye, Q., \& Law, R. (2015). Effect of sharing economy on tourism industry employment. Annals of Tourism Research. doi:10.1016/j.annals.2015.11.018

Festila, M., \& Müller, S. (2017). The Impact of Technology-Mediated Consumption on Identity: The case of Airbnb. Paper presented at the Proceedings of the 50th Hawaii International Conference on System Sciences.

Frizzo-Barker, J., Chow-White, P. A., Mozafari, M., \& Ha, D. (2016). An empirical study of the rise of big data in business scholarship. International Journal of Information Management, 36(3), 403-413.

Fuchs, M., Höpken, W., \& Lexhagen, M. (2014). Big data analytics for knowledge generation in tourism destinations-A case from Sweden. Journal of Destination Marketing \& Management, 3(4), 198-209.

George, G., Osinga, E. C., Lavie, D., \& Scott, B. A. (2016). Big data and data science methods for management research. Academy of Management Journal, 59(5), 1493-1507.

Goddard, W., \& Melville, S. (2001). Research methodology: An introduction. Landsdowne: Juta \& Co, Ltd.

Guttentag, D. (2015). Airbnb: disruptive innovation and the rise of an informal tourism accommodation sector. Current Issues in Tourism, 18(12), 1192-1217. doi:10.1080/13683500.2013.827159

Guttentag, D. (2016). Why tourists choose Airbnb: A motivation-based segmentation study underpinned by innovation concepts. (PhD), University of Waterloo, Waterloo.

Guttentag, D., \& Smith, S. (2017). Assessing Airbnb as a disruptive innovation relative to hotels: Substitution and comparative performance expectations. International Journal of Hospitality Management, 64, 1-10.

Hamari, J., Sjöklint, M., \& Ukkonen, A. (2015). The sharing economy: Why people participate in collaborative consumption. Journal of the Association for Information Science and Technology.

He, W., Wu, H., Yan, G., Akula, V., \& Shen, J. (2015). A novel social media competitive analytics framework with sentiment benchmarks. Information \& Management, 52(7), 801-812.

He, W., Zha, S., \& Li, L. (2013). Social media competitive analysis and text mining: A case study in the pizza industry. International Journal of Information Management, 33(3), 464-472.

Hookway, N. (2008). Entering the blogosphere': some strategies for using blogs in social research. Qualitative Research, 8(1), 91-113.

Ironside, R. (2016). Safety and security is Australian tourism's main strength in an uncertain world. Retrieved from http://www.news.com.au/travel/travel-updates/safety-and-security-isaustralian-tourisms-main-strength-in-an-uncertain-world/newsstory/897b93792b281b07c42cec024fa55c10

Jin, X., \& Wang, Y. (2016). Chinese outbound tourism research: A review. Journal of Travel Research, 55(4), 440-453. doi:10.1177/0047287515608504

Khan, A. Z., Atique, M., \& Thakare, V. M. (2015). Combining lexicon-based and learning-based methods for Twitter sentiment analysis. International Journal of Electronics, Communication and Soft Computing Science \& Engineering (IJECSCSE), 89.

Kozinets, R. V. (2010). Netnography: Doing Ethnographic Research Online. London: Sage. 
Lampinen, A., \& Cheshire, C. (2016). Hosting via Airbnb: Motivations and financial assurances in monetized network hospitality. Paper presented at the Proceedings of the $2016 \mathrm{CHI}$ Conference on Human Factors in Computing Systems.

Leximancer. (2011). Leximancer Manual Version 4. Retrieved from Brisbane:

Liesch, P. W., Håkanson, L., McGaughey, S. L., Middleton, S., \& Cretchley, J. (2011). The evolution of the international business field: a scientometric investigation of articles published in its premier journal. Scientometrics, 88(1), 17-42.

Liu, S., Law, R., Rong, J., Li, G., \& Hall, J. (2013). Analyzing changes in hotel customers' expectations by trip mode. International Journal of Hospitality Management, 34, 359-371. https://doi.org/10.1016/j.ijhm.2012.11.011

Liu, S. Q., \& Mattila, A. S. (2017). Airbnb: Online targeted advertising, sense of power, and consumer decisions. International Journal of Hospitality Management, 60, 33-41.

Lu, W., \& Stepchenkova, S. (2015). User-generated content as a research mode in tourism and hospitality applications: Topics, methods, and software. Journal of Hospitality Marketing \& Management, 24(2), 119-154.

Ma, E., Cheng, M., \& Hsiao, A. (2018). Sentiment Analysis - Bridging Qualitative and Quantitative Analysis: A Review and Agenda for Future Research in Hospitality contexts. International Journal of Contemporary Hospitality Management. 10.1108/IJCHM-10-2017-0704

McAbee, S. T., Landis, R. S., \& Burke, M. I. (2017). Inductive reasoning: The promise of big data. Human Resource Management Review, 27(2), 277-290.

Mcintosh, A. J., \& Siggs, A. (2005). An Exploration of the Experiential Nature of Boutique Accommodation. Journal of Travel Research, 44(1), 74-81. https://doi.org/10.1177/0047287505276593

Mody, M. A., Suess, C., \& Lehto, X. (2017). The accommodation experiencescape: A comparative assessment of hotels and Airbnb. International Journal of Contemporary Hospitality Management, 29(9), 2377-2404.

Nunez-Mir, G. C., lannone, B. V., Pijanowski, B. C., Kong, N., \& Fei, S. (2016). Automated content analysis: addressing the big literature challenge in ecology and evolution. Methods in Ecology and Evolution, 7(11), 1262-1272.

Piryani, R., Madhavi, D., \& Singh, V. K. (2017). Analytical mapping of opinion mining and sentiment analysis research during 2000-2015. Information Processing \& Management, 53(1), 122-150.

Skift. (2016). Airbnb's Latest Investment Values It as Much as Hilton and Hyatt Combined. Retrieved from https://skift.com/2016/09/23/airbnbs-latest-investment-values-it-as-much-as-hiltonand-hyatt-combined/

Small, J., \& Harris, C. (2014). Crying babies on planes: Aeromobility and parenting. Annals of Tourism Research, 48, 27-41.

Smith, A. E., \& Humphreys, M. S. (2006). Evaluation of unsupervised semantic mapping of natural language with Leximancer concept mapping. Behavior Research Methods, 38(2), 262-279.

Son, A. (2005). The measurement of tourist destination image: applying a sketch map technique. International Journal of Tourism Research, 7(4-5), 279-294.

Stuart, R. (2017). Sydney is Airbnb's Australian boomtown, but not everyone is celebrating the website's success. Retrieved from http://www.abc.net.au/news/2017-01-31/airbnbbooming-in-sydney-but-it-could-be-pushing-up-rents/8223900

Sun, M., Zhang, X., \& Ryan, C. (2015). Perceiving tourist destination landscapes through Chinese eyes: The case of South Island, New Zealand. Tourism Management, 46, 582-595. doi:10.1016/j.tourman.2014.08.010

Tussyadiah, L. (2016). Factors of satisfaction and intention to use peer-to-peer accommodation. International Journal of Hospitality Management, 55, 70-80. 
Tussyadiah, L., \& Pesonen, J. (2015). Impacts of Peer-to-Peer Accommodation Use on Travel Patterns. Journal of Travel Research. doi:10.1177/0047287515608505

Tussyadiah, L., \& Zach, F. (2016). Identifying salient attributes of peer-to-peer accommodation experience. Journal of Travel \& Tourism Marketing, 1-17.

Verhage, J. (2016). One Wall Street Firm Expects Airbnb to Book a Billion Nights a Year Within a Decade. Retrieved from https://www.bloomberg.com/news/articles/2016-04-11/one-wallstreet-firm-expects-airbnb-to-book-a-billion-nights-a-year-within-a-decade

Walls, A. R. (2013). A cross-sectional examination of hotel consumer experience and relative effects on consumer values. International Journal of Hospitality Management, 32, 179-192. https://doi.org/10.1016/ji.ijhm.2012.04.009

Wang, D., \& Nicolau, J. L. (2017). Price determinants of sharing economy based accommodation rental: A study of listings from 33 cities on Airbnb. com. International Journal of Hospitality Management, 62, 120-131.

Xiang, Z., Schwartz, Z., Gerdes, J. H., \& Uysal, M. (2015). What can big data and text analytics tell us about hotel guest experience and satisfaction? International Journal of Hospitality Management, 44, 120-130.

Yannopoulou, N. (2013). User-Generated Brands and Social Media: Couchsurfing and Airbnb. Contemporary Management Research, 9(1), 85-90. doi:10.7903/cmr.11116

Young, C. A., Corsun, D. L., \& Xie, K. L. (2017). Travelers' preferences for peer-to-peer (P2P) accommodations and hotels. International Journal of Culture, Tourism and Hospitality Research, 11(4), 465-482.

Zervas, G., Proserpio, D., \& Byers, J. W. (2017). The rise of the sharing economy: Estimating the impact of Airbnb on the hotel industry. Journal of Marketing Research, LIV, 687-705.

Zhou, L., Ye, S., Pearce, P. L., \& Wu, M.-Y. (2014). Refreshing hotel satisfaction studies by reconfiguring customer review data. International Journal of Hospitality Management, 38, 110. 


\section{Appendix 1:}

\begin{tabular}{|c|c|}
\hline Favourable & Unfavourable \\
\hline accuracy, accurate & abuse, abuse, abusive \\
\hline admire, admired & angry \\
\hline appreciation & annoy, annoyed, annoying \\
\hline awesome & bad \\
\hline beautiful & blame, blamed \\
\hline best & broken \\
\hline $\begin{array}{l}\text { celebrate,celebrated,celebrating,celebration,celebr } \\
\text { ations }\end{array}$ & complicated \\
\hline cheer,cheers & condescending, condescended \\
\hline $\begin{array}{l}\text { commend,commendable,commendation,commen } \\
\text { ded,commending }\end{array}$ & criticism,criticisms, criticize, critics \\
\hline $\begin{array}{l}\text { complimented,compliment, } \\
\text { compliments }\end{array}$ & crap,crappy \\
\hline convenience,convenient,conveniently & cutting \\
\hline courteous & damn \\
\hline creditable & delay \\
\hline eager,eagerly & detract,detracted,detracting,detractor \\
\hline easiest,easy & difficult,difficulty \\
\hline effective,effectively,efficiency,efficiently & disappointed,disappointing,disgusting \\
\hline endorse & dislike \\
\hline excellent & dissatisfied \\
\hline fabulous & dubious \\
\hline fantastic & embarrassed,embarrassing \\
\hline fast & fail, failed, failing, fails, failure \\
\hline favor,favourable,favorable,favour & fault \\
\hline friendly & fear,fearful \\
\hline happiness,happy & frustrate, frustrated, frustrating \\
\hline helpful & hassled \\
\hline hero & horror,horrible \\
\hline honor, honored, honour, honoured & incident \\
\hline impress, impressed, impressing, impressive & inconvenient \\
\hline incredible & lack \\
\hline joyful & mess,messed \\
\hline kudos & negative \\
\hline lovely & offence, offensive \\
\hline nice & poor, poorly \\
\hline performance & problem, problems \\
\hline pleasant & refuse \\
\hline polite,politely & ridiculous \\
\hline praise, praised, praised, praising & rubbish \\
\hline quality & rude \\
\hline quick & saddened,saddening \\
\hline reliable,reliably & scolded \\
\hline stable & severe \\
\hline succeed, succeeded,succeeds, success, successful & shit \\
\hline superior & shock, shocked, shocking, shocks \\
\hline trustworthy & slow \\
\hline wonderful & terrible \\
\hline good & trouble,troublesome \\
\hline
\end{tabular}


Appendix 2:

\begin{tabular}{|c|c|c|c|c|c|}
\hline Themes & Concepts & Hits & Themes & Concepts & Hits \\
\hline \multirow[t]{29}{*}{ Location } & Walk & 55659 & & comfortable & 50290 \\
\hline & Restaurants & 35337 & & clean & 50786 \\
\hline & Easy & 34646 & & everything & 48759 \\
\hline & Station & 22835 & & house & 34564 \\
\hline & Shops & 19761 & & nice & 32798 \\
\hline & City & 23596 & & room & 31735 \\
\hline & Beach & 23096 & & bed & 19797 \\
\hline & Bus & 16033 & & view & 21859 \\
\hline & Quiet & 17061 & & need & 16177 \\
\hline & Short & 14065 & & bathroom & 10747 \\
\hline & Walking & 13975 & & kitchen & 13415 \\
\hline & Cafes & 11177 & & space & 11956 \\
\hline & Transport & 12660 & & breakfast & 9036 \\
\hline & Day & 10714 & & night & 11002 \\
\hline & Coffee & 9467 & & living & 5251 \\
\hline & Street & 8814 & & use & 7192 \\
\hline & Convenient & 11371 & & sheets & 6202 \\
\hline & Bondi & 8442 & & bedroom & 6155 \\
\hline & Parking & 8981 & & water & 4104 \\
\hline & Airport & 6886 & & shower & 4291 \\
\hline & Morning & 6293 & & floor & 2688 \\
\hline & Food & 5964 & & & \\
\hline & Nearby & 6280 & & & \\
\hline & Ferry & 4875 & & & \\
\hline & Garden & 4327 & & & \\
\hline & Old & 3554 & & & \\
\hline & Park & 4359 & & & \\
\hline & Door & 4880 & & & \\
\hline & Noise & 4288 & & & \\
\hline \multirow[t]{16}{*}{ Host } & host & 58316 & Recommend & recommend & 43070 \\
\hline & home & 51456 & & enjoyed & 16664 \\
\hline & welcoming & 40725 & & experience & 19144 \\
\hline & lovely & 31004 & & loved & 16479 \\
\hline & perfect & 27033 & & best & 9590 \\
\hline & helpful & 27009 & & check & 8017 \\
\hline & time & 30037 & & Airbnb & 6855 \\
\hline & friendly & 24221 & & visit & 7771 \\
\hline & beautiful & 18247 & & & \\
\hline & wonderful & 15910 & & & \\
\hline & arrival & 17498 & & & \\
\hline & amazing & 13345 & & & \\
\hline & family & 11730 & & & \\
\hline & warm & 7973 & & & \\
\hline & communication & 6943 & & & \\
\hline & $\operatorname{dog}$ & 2996 & & & \\
\hline
\end{tabular}

*Hits denotes the number of text blocks in the project associated with the Theme 